\title{
Б. ШУЛЬЦ І І. БАБЕЛЬ: ДО ТИПОЛОГІї ТЕКСТУ ПЕРЕХІДНОГО ПЕРІОДУ
}

\author{
Еліна Свенцицька
}

\author{
Доктор філологічних наук, професор, професор, \\ Кафедра слов'янської філології та журналістики, \\ Таврійський національний університет імені В. І. Вернадського (УКРАЇНА), \\ 01042, Київ, вул. Джона Макейна, 33, \\ e-mail: elinasvm@gmail.com
}

\section{РЕФЕРАТ}

Mema. Статтю присвячено порівняльному аналізу двох повістей: «Цинамонові крамниці» Б. Шульца і «Кінармії» I. Бабеля. Мета роботи - зіставити ці повісті, показати близькість їхніх художніх світів в спільних ідеологічних моментах, в просторовій організації, у співвідношенні автора і героя. Дослідницька методика. Перш за все, використано порівняльно-типологічний метод, завдяки якому було визначено риси, які конституюють особливий тип тексту на межі художніх парадигм. Аналізуючи конкретні твори, ми користувалися методом цілісного аналізу, розробленим донецькою філологічною школою, а також методом герменевтичного аналізу, базуючись на положеннях Г.- Г. Гадамера, висловлених статті «Істина і метод» - тобто, відтворення смислової перспективи, властивої даному авторові. Результати. Виявлено, що дані твори схожі за жанровою структурою. Також стало зрозуміло, що ці твори рефлектують спільні закономірності духовного життя - богозалишеність та ії наслідки, відчуття зламу історичного часу. Повісті Б. Шульца і І. Бабеля пов'язані також подібним баченням простору. В описі природного простору один з головних мотивів - мотив надлишку сил природи, її життєвої повноти. Проведений аналіз показав, що в даних творах є спільні риси суб’єктної організації - тут автор розповідає про події не безпосередньо, а з точки зору головного героя. В обох творах цей герой-оповідач має дві іпостасі: з одного боку, герой як суб'єкт дії й переживання, з іншого - як призма і погляд збоку на зображуваний світ. Наукова новизна. У статті вперше здійснено порівняльний аналіз повістей Б. Шульца «Цинамонові крамниці» і І. Бабеля «Кінармія» крізь призму аналізу простору, часу та суб’єктної організації. Вперше виявлені особливості авторського погляду, характерні для тексту межової ситуації: це погляд вражений і це погляд зупинений. Практичне значення. Стаття може бути використана для подалышого вивчення типологічних рис творів Б. Шульца і І. Бабеля. Наукові результати можуть бути застосовані під час написання курсових та дипломних робіт.

Ключові слова: простір, час, автор, герой, модернізм, оповідь.

\section{B. SHULZ AND I. BABEL: TOWARD A TYPOLOGY OF TEXT OF THE TRANSITIONAL PERIOD}

\section{Elina Sventsytska}

Doctor of Philological Sciences, Full Professor, Department of Slavic Philology and journalism, V. I. Vernadsky Taurida National University (UKRAINE), 01042, Kyiv, 33, John Mackain str., e-mail: elinasvm@gmail.com

\section{ABSTRACT}

Aim. The article is devoted to the comparative analysis of two short stories: «Korichniye lavki» («The cinnamon shops») by B. Schultz and «Konarmiya» («Red cavalry») by I. Babel. The goal of the work is to juxtapose these stories, to show the closeness of their artistic worlds - both in the general ideological elements, and in the spatial organization, and in the relations of the author and character. Methods. First of all, a comparative-typological method was used, which helped to define the features constituting a special type of text 
on the borderline of artistic paradigms. Analyzing specific works, we used the method of holistic analysis developed by the Donetsk philological school, as well as the method of hermeneutic analysis based on the principles of H.-G. Gadamer expressed in the article «Truth and method», i. e. reflecting the semantic perspective characteristic of the author. Results. It was shown that these works have similar genre structure. It also became clear that these works reflect the general tendencies of spiritual life - the godforsakennes and its consequences, a sense of fracture of historical time. The stories of B. Schultz and I. Babel are also connected by a similar vision of space. The description of natural space shows one of the main themes - the excess of nature's forces, the vital completeness of nature. The analysis showed that these works have common features of the subject organization: the author does not tell us about the events directly, but from the point of view of the main character. In both works, this main character-narrator has two hypostases: on the one hand, he is the subject of action and experience, on the other - the prism and the outside perspective of the depicted world. Scientific novelty. The article carried out for the first time a comparative analysis of the short stories by B. Schultz «Korichniye lavki» («The cinnamon shops») and I. Babel «Konarmiya» («Red cavalry») through the prism of space, time and subjective organization analysis. For the first time the peculiarities of the author's view, typical for the text of the boundary situation, are revealed: it is a stricken view and an arrested view. Practical significance. The article can be used to further study the typological features of B. Schultz and I. Babel works. Scientific results can be applied in writing term papers and diploma papers.

Key words: space, time, author, character, modernism, narrative.

Життя і творчість Б. Шульца і І. Бабеля припали на 20-ті роки - складний період у розвитку світової літератури, період зламу культурної традиції. Ці письменники - євреї в неєврейському світі, обидва написали небагато, обидва рано померли. Обох авторів дослідники зараховували до різних літературних напрямів - і в той же час підкреслювали незвідність їх творчих індивідуальностей до жодного з них. У творах обох авторів дослідники знаходили взаємодії і перетини безлічі культурних контекстів, цитат і алюзій.

Виникає необхідність розібратися в своєрідності тексту, який породжує можливості надбудови над ними кількох референтних рівнів.

Мета нашої роботи - зіставити повісті «Цинамонові крамниці» Б. Шульца i «Кінармія» І. Бабеля, показати близькість їх художніх світів і в загальних ідеологічних моментах, і в просторовій організації, i у взаємовідношеннях автора і героя.

Відразу ж відзначимо жанрову спорідненість цих творів: обидва представляють собою великий твір, що складається 3 малих, об'єднаних спільними героями і химерною, мозаїчною фабулою. Кожна з частин відзначена, з одного боку, зовнішньою незакінченістю, відкритістю в простір цілого, але, з іншого боку, внутрішньою завершеністю процесу перетворення реальності. У Б. Шульца і І. Бабеля розділ - це монада, один момент в становленні цілого, в якому, однак, це ціле повністю присутнє, чому і зв'язок між монадами - не зовнішній (фабульний), а внутрішній (емоційний, ідеологічний). В обох авторів, по суті, одна ситуація породження тексту - ситуація розкладу єдності повсякденного життя і буття, утриманню якої й служить текст.

\section{Рефлексія богозалишеності}

Головна закономірність духовного життя, яка стоїть за цими творами і в них відрефлектована, - богозалишеність. В «Кінармії» про це постійно говорять герої: «Бог від нас, холуїв, ушився, доля наша індичка, життя наше копійка» («Життєпис Матвія Павличенки...»), «Ти бога поважаєш, зраднику» («Після бою»). Звідси всезагальне відчуття зламу історичного часу - «життя похит- 
нулося» («Життєпис Матвія Павличенки...»). Більш розгорнуто деформація часу виражена у Б. Шульца: «Була мить, коли час, дикий і збожеволілий, виламується 3 одноманіття подій i, ніби втеклий волоцюга, жене $з$ криком через поля навпростець» («Пан»); «Кожному відомо, що в шерезі звичних і нормальних років здивачілий час іноді народжує 3 власного лона інші, особливі рокивиродки, що їм, ніби шостий малий палець на руці, виростає тринадцятий фальшивий місяць» («Ніч великого сезону»). Час катастрофічний, відумерлий, божевільний, проте ці ознаки згладжені, розлиті в просторі, і це причина виникнення тієї «деградованої дійсності», про яку писав А. Сандауер [3, с. 2526].

Богозалишеність же проявляється в повісті Б. Шульца парадоксальним способом - в політеїзмі (тут і язичницький Пан, і Бог Старого Заповіту, і Христос), який відтворюється за принципом нонієрархії, кожний з богів представлений живим, владним і таємничим, і водночас глибоко байдужим до людини й ii долі. Цей політеїзм, скоріше за все, спричиняє поєднання язичницької, юдейської та християнської символіки, про яке пише в своїй статті Р. Мних [2, с. 58].

3 боку ж людини і у Б. Шульца, і у І. Бабеля відбувається своєрідне провокування абсолюту. В «Кінармії» герої не тільки постійно виголошують блюзнірства, але й явно оскверняють святині (і юдейські, і християнські). Причина цих дій - не безрелігійність, але, навпаки, прагнення упевнитися в існуванні цього абсолюту, знущаючись, спонукати його до дій, таким чином проявивши свою присутність в світі; вони хочуть не вірити, а знати, що він існує: «В глибині ніші, що відкрилася, на тлі неба, яке борознили хмарами, бігла бородата фігурка в помаранчевому кунтуші. Хрипке виття роздерло тоді наш слух. Парубок, що стояв зі мною поруч, закричав i, опустивши голову, кинувся бігти, хоча бігти було не від чого, тому що фігура в ніші була всього тільки Ісус Христос - саме незвичайне зображення бога з усіх бачених мною в житті». Воскреслий на мить Бог виявляється всього лише зображенням, але реакція героїв показує, що таке оживлення їм видається цілком можливим.

Аналогична ситуація виникає і в «Цинамонових крамницях». Батько головного героя, Яків, веде діалог з Богом-Отцем: «Той діалог був небезпечний, як розмова блискавиць. Ламані лінії його рук розривали небо на шматки, а у проміжках визирав лик Єгови, набряклий гнівом і запльований прокльонами» («Ошаління»). Закінченням цього діалогу стає дуже своєрідний жест: «...зі страшним прокляттям він могутнім струменем вихлюпував вміст уриналу за вікно - в ніч, усю заповнену гудінням, як мушля». Богоборство, закладене в імені, обертається цинічним провокуванням напівбожевільного, і саме такою, напівбожевільною, людина цілком влаштовує цього деміурга: «Іноді він ставив два крісла одне проти одного i, спершись руками на бильця, розгойдувався вперед і назад ногами, в той же час просвітленими очима шукаючи на наших обличчях виразів подиву і підтримки. 3 Богом він, здавалося, примирився цілковито. Ночами у вікні спальні іноді з'являвся лик бородатого Деміурга, залитий темно-пурпуровим бенгальським світлом; якийсь час він приязно дивився на батька...». Ця ситуація, з одного боку, є іронічною реалізацією 
євангельського «Зверніться і будете як діти», а 3 іншого боку - в реальності тексту - проміжним етапом на шляху перетворення людини в тварину (спочатку в птаха, потім у таргана).

Перетворення відбувається цілком логічно, коли людина, покинута Богом, стає іграшкою ворожих їй сил. Перетворення Якова подається автором у подвійному висвітленні. 3 одного боку, це божевілля; коли людина уявляє себе не людиною, неадекватність іï поведінки впадає в очі оточуючим: «Часом він видряпувався на карниз і прибирав нерухому позу симетрично до опудала грифа, підвішеного на стіні потойбіч вікна. У цій непорушній скуленій позі, 3 туманним поглядом і хитрим усміхом, він простоював годинами, щоби знагла, щойно хтось увійде, затріпотіти руками, наче крилами, i, мов півень, пропіяти» («Ошаління»). Але, з іншого боку, поступово безумство стає реальністю, що визнається тими, хто бачить героя - спочатку, в розділі «Птахи», син помічає схожість батька 3 кондором («Коли він (кондор) сидів навпроти батька, знерухомілий у монументальній позі прадавніх богів Єгипту... то завдяки своєму кам'яному профілю міг здаватися батьковим старшим братом»), батько ж, з розвитком божевілля, «меншає, худне і немовби скарлючується», «батько 3 дня на день зменшується - немов горіх, що всихається всередині шкаралущі», i, врешті-решт, хлопчик думає, що опудало кондора - це його батько («Таргани»).

Аналогічним чином відбувається перетворення на таргана: спочатку навколишні бачать, що Яків уявляє ним себе («Батькова поведінка змінилась... Він став уникати нас, ховатися цілими днями по закутках і шафах або під периною...»), але те, що відбувається всередині, поступово виходить назовні і стає незаперечним фактом: «Жахна подібність із кожним днем проглядала все виразніше. Батько перетворювався на таргана».

При цьому в одному розділі «Таргани» стикаються чотири іпостасі Якова: він, як ми бачили, і птах, і тарган, на початку він мертвий («Батька тоді вже не було»), в кінці (і в наступних розділах) він живий («батько в дорозі, він їздить країною, він комівояжер»).

Отже, осмислення ситуації перетворення у Б. Шульца явно відрізняється від осмислення аналогічної ситуації у Ф. Кафки. У Ф. Кафки людина, залишена Богом, самотня, і перетворення невмотивовано, жертва обрана довільно, це рок, що виходить із хаосу, перед яким людина беззахисна. У Б. Шульца людина беззахисна насамперед перед самою собою, перед тими примарами i фантомами, які народжує іiі власна душа, в ній виявляється закладеними будьякі перетворення.

\section{Людина заступас місце Бога: наслідки}

«Бог помер», отже, людина може встати на його місце. Саме тому в поведінці героїв «Кінармії» «поєднуються пошук правди, прагнення справедливості 3 жорстокістю...» [1, с. 72]. Адже, за логікою героя, людина, яка стала на місце Бога, починає творити суд за власним розумінням: «Тепер кожний кожного судить. I на смерть присуджує, дуже просто...» («Івани»). Це явище в «Кінармії» $\epsilon$ буденним, кожний може бути і суддєю, i підсудним, i жертвою, i катом. 
Присвоєння божествених прерогатив нічого людині не гарантує, вона лише стає ще більш уразливою в цьому світі, що нищиться кожну мить.

У Якова в повісті «Цинамонові крамниці» під час божевілля з'являється така ж ідея, як у бабелівських героїв, - встати на місце Бога: «Коротше кажучи, - завершував батько, - ми хочемо створити людину ще раз, але тепер за образом і подобою манекена» («Трактат про манекенів, або Нова Книга Буття»). В алюзії на біблійний вірш, таким чином, місце Бога займає манекен, а атрибут творення переноситься на людину.

Головна ідея «Трактату про манекенів», що належить Якову і викладений його сином, якраз і полягає в тому, що під час відсутності Бога можливість створення нового життя, нового світу може бути розлита в матерії, і іï може зреалізувати кожна людина: «Матерії дано безконечну плідність, невичерпну життєву міць і разом з нею звідницьку силу спокуси, що заманює нас у формотворення... Ми хочемо бути творцями у власній, нижчій сфері, прагнемо власної творчості, прагнемо насолоди творення, словом, прагнемо деміургії».

Відсутність єдиного начала, що творить все, компенсується в художньому світі застосуванням атрибута творення, народження до безлічі метафізичних i природних реалій. Світ стає весь непередбачено здатним до народження, але це народження - спотворення, створення фантомів, які перебувають на межі життя і смерті: «...здивачілий час іноді народжує з власного лона інші, особливі рокивиродки...» («Ніч великого сезону»); «Коли він сидів отак у несвідомому вегетативному безрусі... в різних місцях зарослого волоссям тіла починало пробиватись якесь незнане, невисловлене майбутнє, ніби потворний наріст, що чудернацько збільшується до небачених параметрів...» («Пан Кароль»); «Тієї довгої й порожньої зими темрява зародилася в нашому місті величезним, у сто разів більшим за звичні, урожаєм» («Віхола»); «...а ніч у своїй невичерпній плодючості не знаходить собі кращих занять, ніж вигадувати все нові конфігурації» («Цинамонові крамниці»). Квінтесенцією такого знівеченого народження, безумовно, $є$ повернення птахів Якова в кінці повісті.

Власне, різні атрибути Бога авторів цікавлять тому, що в них різні оповідні завдання: І. Бабелю необхідно вийти за межі літератури i, дивлячися на вбивства, руйнування, інші протиприродні речі, навчитися органічно, природно представляти їх в слові, творчо опанувати долю, що веде до смерті. I в цьому оволодінні він цілком свідомо підходить до тієї межі, де «кончается искусство, а дышит почва и судьба» (Б. Пастернак). Б. Шульцу, навпаки, необхідно розширити межі літератури до буття, виявивши його творчу субстанцію, розповсюдивши іiі в безкінечності і відчувши іiі як в широкому сенсі поетичну. Парадоксальним чином Б. Шульц не створює світ, а світ сам створюється не тільки в тому смислі, що події, які в ньому відбуваються, постають більш важливими, ніж ті, що відбуваються з героями, але й тому, що кожна 3 його реалій створює своє власне буття, а автор тільки організує співвідношення цих процесів.

\section{Особливості простору}

Повісті Б. Шульца і І. Бабеля пов’язані також баченням простору. В описі природного простору один з головних мотивів - мотив надлишку сил природи, 
iï життєвої повноти. «Кінармія»: «Поля пурпурового маку квітують навколо нас, полуденний вітер грає в жовтіючому житі, незаймана гречка встає на виднокрузі, як стіна далекого монастиря» («Перехід через Збруч»); «...а за вікном в саду під чорною пристрастю неба переливається алея. Спраглі троянди колишуться в пітьмі» («Костел в Новограді»); «Ніч летіла до мене на жвавих конях. Крик обозів оголошував всесвіт. На землі, оперезаній виском, меркли дороги. Зірки виповзли $з$ прохолодного черева ночі, і кинуті села спалахували над обрієм» («Івани»). «Цинамонові крамниці»: «Аделя приходила світлистим ранком, ніби Помона у вогні розжарених днів, сиплячи 3 кошика барвною красою сонця - лискучі, налиті водою під прозорістю шкірки черешні, таємничі чорні вишні, що пахощами перебивали сутність власного смаку» («Серпень»); «I там він уже не був садом, а пароксизмом шаленства, вибухом сказу, цинічною безсоромністю та розпустою» («Пан»); «Кольорова небесна мапа збільшилася до розмірів неосяжного склепіння, на якому згромадилися фантастичні материки, океани й моря, покреслені лініями завихрень і зоряних течій, сяйливими лініями небесної географії» («Цинамонові крамниці»).

В обох випадках перед нами не пейзаж в звичайному сенсі - не опис автономної природи. Ця надмірність створює другий план: невидиму внутрішню динаміку, гру природних реалій. Особливо це важливо для Б. Шульца, для якого ця всеприродна рухливість обертається здатністю просторових реалій переходити за власні межі, створюючи певну самоцінну дійсність (в цьому сенсі особливо показові описи зимового неба в розділі «Цинамонові крамниці» та саду в розділі «Пан»). Але тут і виникає своєрідна провокація: звичайний пейзаж («заспані дні зими»), переходить в інобуття непомітно, без будь-якої межі; буденне, життєве й чудесне, буттєве з'єднані, звичайне постійно переходить у надзвичайне. Предметом зображення тут стає ця єдність буття, що таємно ллється і переливається в різні форми, жодна з яких не є вичерпною і готовою. При цьому автор провокує читача прийняти саме цю конкретну форму за остаточний прояв цієї єдності - і відразу ж спростовує іiі самодостатність.

У «Кінармії» такі описи потрібні теж для провокації, але іншого роду. Практично в кожному розділі всередині опису краси, буяння, гри природи можна знайти фрази типу: «Запах крові й вбитих коней скраплює у вечірню прохолоду» («Перехід через Збруч»); «Роздягнений труп валяється під укосом» («Костел в Новограді»); «Піднявши на себе сідло, я пішов по розгорнутій межі і коло повороту зупинився через свою нужду» («Івани»). Буквально на території одного абзацу тут стикається естетичне з антиестетичним, і цю ситуацію можна трактувати подвійно: вбивства, муки, фізіологічні відправлення, представлені на вербальному рівні, розчиняються й нейтралізуються красою природи, або навпаки, краса природи непомітно, але необоротно просякається смертю. I. Бабель, як і Б. Шульц, грає двоїстістю, заперечуючи самодостатність того чи іншого начала. В даному випадку виявляється просто спільна основа краси й іiі руйнування, яка міститься в чомусь простому й відчутному, там, де протилежності найбільш нещадно стикаються і де в той же час з найбільш нещадною переконливістю оголюється їх глибинна єдність. 
Ще одна особливість, яка поєднує ці твори - таємниче життя простору, при чому не природного, а речовинного. «Кінармія»: «У підніжжя картини був покладений сонцем прямий промінь. У ньому роївся блискучий пил. Прямо на мене 3 синьої глибині ніші спускалася довга фігура Іоанна» («Пан Аполек»); «Його циліндр погойдувався над нами, як чорна башточка» («Гедалі»); «Кулі скиглять і вищать» («Смерть Долгушова»). «Цинамонові крамниці»: «Темним помешканням на другому поверсі кам'яниці на площі Ринок щодня проходило ціле велетенське літо: тиша тремких нашарувань повітря, квадрати блиску, що снили свої розпечені сни на долівці...» («Серпень»); «Ліжка, не застелювані цілими днями, завалені вим'ятою, витоптаною в тяжких снах постіллю, стояли, ніби глибокі човни, готові от-от відчалити у вогкі і непролазні лабіринти якоїсь чорної, беззоряної Венеції» («Манекени»); «3 шелестіння листків та безконечного перегортання документів виростало розграфлене у клітинку й порожнє існування цього приміщення» («Ніч великого сезону»).

Речі, як і природні реалії, живуть своїм окремим життям. В обох випадках ця закономірність виражає нестабільній характер навколишнього світу, його розірваність. I в той же час єдність життя, що розкололася на безліч маленьких життів, залишається незнищуваною і незмінною по суті своїй в кожному 3 них. Крім того, в такій постановці деталей безумовно відбивається загальномодерністська театралізація життя, яка обома авторами сприймається буквально. Тут знімається поділ на театр і дійсність, всі життєві реалії розігрують перед сприймаючим суб'єктом п'єсу своєї «екзистенції»: «Здавалося, ті дерева спричиняють вихор, театрально напинаючи свої крони, щоб у патетичних вигибасах зіграти напоказ усією вишуканістю листяних віял зі сріблястими, мов хутра породистих лисиць, підчеревцями» («Серпень»); «Тим часом у їдальні вже готувався сценарій вечора. ... Ах! Та їм би цілком вистачило й одного набитого тирсою п’єро на двох, лиш одне-два слова, на які вони здавна чекали, щоб виступити зі своєю здавна підготовленою роллю, що так само здавна лізла їм на вуста, сповнена солодкої і страшної гіркоти, шалено захоплива, наче сторінки любовного роману, який ковтаєш уночі разом зі сльозами, пущеними по розпалених щоках» («Манекени»); «Часом виникає враження, ніби тільки на малому відтинку перед нами все більш-менш може вкластися в образ бульвару 3 великого міста, тим часом як уже по боках цей імпровізований маскарад розв'язується та розпускається i, неспроможний дограти власну роль, розпадається за нашими спинами на гіпсові уламки, перетворюючись на звалище якогось величезного й порожнього театру» («Вулиця Крокодилів»).

Символічно, що в розділі «Цинамонові крамниці» герой йде 3 справжнього театру, і цей театр виявляється рівноправним $з$ тим таємним життям природи і речей, яке він спостерігає під час своїх блукань містом. «Щоб на кожен жест був інший актор», - це основа теорії безумного Якова, про якого в розділі «Цинамонові крамниці» говориться: «Усі нічні тріски та хрускоти, потаємне скрипуче життя підлоги знаходили в ньому непомильно чутливого спостережника, підглядальника і спільника». Таким чином, речовинний і природний світи, що існують за законом театру, маніфестують цю свою театральну сутність 
перш за все через потребу в глядачі, саме тому Яків був «запроданий, заприсяглий сферам іншого».

Те ж саме поєднання таємного життя, укладеного у всесвіті, і театральності (а також карнавальності) можна побачити й у власному висловлюванні Б. Шульца про повість в листі до С. Віткевича: «,Цинамонові крамниці” дають певний рецепт для дійсності, створюють певний, особливий рід субстанції. Субстанція цієї дійсності знаходиться в стані безперервної ферментації, проростання, прихованого життя. Не існує мертвих, твердих, обмежених речей. Все виходить за власні межі, лише мить перебуваючи в певній формі, щоб залишити іï при першій слушній нагоді. Встановленим тут $є$ лише певний, крайній монізм субстанції, для якої окремі предмети - тільки маски. Тут постійно присутня атмосфера ... зворотного боку сцени, де актори, знявши костюми, підсміюються над пафосом своїх ролей» [4, с. 444-445].

Даною закономірністю, можливо, пояснюється ті невідповідності в поведінці героїв, про які пише в своїй статті М. Шалата: «Як реагували батьки на пропажу сина, чи знайшовся гаманець - про це Шульц не завдає собі праці розповісти. У його творах взагалі ніхто ні за що не відповідає. Шльома в «Санаторії під клепсидрою», зайшовши в гості, в пориві еротичних фантазій ховає за пазуху туфлі, спідничку, намисто Аделі ... чи була виявлена пропажа, чи був покараний Шльома або господар... - точно так само невідомо» [5, с. 40]. За свою поведінку героям і не потрібно відповідати, тому що вони - лише актори, існуючі заради певного жесту, і коли цей жест зроблений, вони просто перестають цікавити автора. Це твердження можна було б вважати безпідставним, якби не ряд героїв, що виникають на початку оповіді і повністю зникають 3 фінальних іiі частин: Тлуя, Мариська, тітка Агата, іiі чоловік, Еміль, Луція («Серпень»), Польда і Пауліна («Манекени») та ін. Ці герої зазвичай діють в межах одного розділу, роблять химерні вчинки-жести (Тлуя, що осідлала стовбур дерева; тітка Перазія, що лаялася з Аделю і врешті-решт зникла; прикажчик Теодор, що смішно викривляв обличчя і т.ін.). Створюється враження, що ці герої рівноправні з речами й реаліями природи в плані здійснення такого роду жестів, чому вони поступово й витісняються 3 оповіді, замінюючись речами. Функцію героїв виконують, наприклад, тканини в розділі «Ніч великого сезону», морок в розділі «Страшний вітер» та ін.

\section{Взасмовідношення автора і героя}

В даних творах можна побачити подібні риси суб'єктної організації - в обох автор оповідає про події не безпосередньо, а з точки зору головного героя, одночасно і суб'єкта слова, і суб'єкта бачення. У «Кінармії» таким героєм-оповідачем є Лютов, причому він проявляє себе двояко. 3 одного боку, він суб'єкт переживання й оцінки подій, що відбуваються, він захоплений ходом життя, вкрай суперечливого й хаотичного (саме він, наприклад, хоче знайти «єврейського бога в стакані чаю», він в поставі Савицького «побачив владну бадужість татарського хана», він сумує за бджолами і т. ін.). 3 іншого боку, він же - суб'єкт зображення, який спостерігає те, що відбувається ззовні, він - 
розкрита точка зору на внутрішню дисгармонію і протиприродність руху, що втягує в себе героїв.

Почасту ці дві іпостасі відділені одна від одній. Наприклад, в оповіданні «Сашка Христос»: «Він був громадський пастух в станиці і не робив важкої роботи з чотирнадцяти років, з тієї пори, коли захворів поганою хворобою. Це усе так було...» (далі слідує власне оповідь). Те ж саме в оповіданні «Пан Аполек»: «Чарівне і мудре життя пана Аполека ударило мені в голову, як старе вино. У Новоград-Волинську, в поспіхом зметеному місті, серед скорчених розвалин, доля кинула мені під ноги укрите від світу євангеліє» (далі розповідається про пана Аполека). Автор же, природно, не ототожнюється 3 цими суб'єктами, його функція - здійснення внутрішньої динаміки і взаємодії свідомостей.

У Б. Шульца також автор оповідає про події не безпосередньо, а з точки зору головного героя, одночасно і суб'єкта слова, і суб'єкта бачення. Між героєм і автором в творі розгортаються складні й неоднозначні стосунки. 3 одного боку, герой наближається до автора. Це проявляється в той жазі деміургії, яка охоплює божевільного Якова. I в цілому його погляд на реальність, висловлюваний в розділах про манекени, парадоксальним чином виявляється спорідненим тим особливостям авторського світу, про які ми вже говорили. Так, Б. Шульц відтворює якесь таємне життя побутових реалій, а Яків «увесь час контактує з невидимим світом темних закамарків, мишачих нір, трухлявих порожнин під підлогою та коминових нутрощів» («Цинамонові крамниці»). Так же само й міркування Якова про його гіпотетичні творення близькі реальному трактуванню героя в «Цинамонових крамницях»: «Наші витвори не будуть героями багатотомних епопей. Їхні ролі будуть короткі, малослівні, характери без планів на дальший розвиток. Часто ми завдаватимемо собі праці покликати ïх до життя лише заради єдиного жесту, одного слова, лише на одну мить» («Трактат про манекенів...»). Даний фрагмент, до речі, поза контекстом виглядає як розмисли автора літературного твору.

Таким чином, божевільний герой прагне стати адекватним автором, точніше, безумство перестає бути таким, як тільки стає не рисою особистості, а способом перетворення реального світу. 3 іншого боку, автор прагне дистанціюватися від такого героя, створюючи між собою і світом проміжні ланки. Таким посередником є, по-перше, син головного героя, Якова, що розповідає про нього і про своє дитинство. Цей герой не випадково безіменний, так маркується його позаособистісна функція, він існує як своєрідна призма, як погляд збоку: «Я так і бачу його у світлі кіптявої лампи - ось він сидить навпочіпки серед подушок, під великим різьбленим узголів'ям ліжка й величезною тінню власної голови на стіні, ось похитується в безмовній медитації» («Ошаління»).

По-друге, тут представлена вербалізуюча іпостась суб'єкта оповіді. Читачеві час від часу нагадують, що перед ним не просто розгортання подій, але створення тексту, акцентується «подія оповіді»: «Тож і я - записуючи ці свої оповіді й вилаштовуючи шерегами історії про батька на зужитих берегах іiі тексту, чи не впадаю в потаємну надію, що колись вони непомітно вростуть між 
зжовклими пї, найчудовнішої напіврозсипаної книги, аркушами, що увійдуть у велике шелестіння ï сторінок, і воно їх цілком поглине?» («Ніч великого сезону»); «Тут заради точності у звітуванні ми повинні описати певний дрібний і несуттєвий інцидент, який трапився в цей момент батькової лекції, хоч ми й не надаємо йому жодної ваги. Цей інцидент, цілком незрозумілий та безглуздий у ланцюгові подій, піддається тлумаченню хіба що з точки зору залишкового автоматизму, без попередніх обставин і тяглості, як своєрідна злостивість об'єкта, перенесена до психічної царини. Читачеві радимо проігнорувати його 3 такою ж легкістю, що й ми» («Трактат про манекенів»); «Кілька разів у ході нашого звітування ми ставили певні застережні знаки, якнайтактовніше виражаючи наші перестороги. Уважний читач не буде заскочений остаточним поворотом ситуації. Ми згадували вдавано-ілюзійний характер цієї дільниці, проте ці слова мають надто остаточне і принципове значення, щоб окреслити половинчасту й нерішучу її сутність» («Вулиця Крокодилів»). Займенник «ми» тут також не випадковий, оскільки означає реальну багатосуб'єктність цієї оповідної інстанції, єдиний автор розшаровується на автора - свідка подій і автора, який пише про події. Наявність цих суб'єктів на межі між автором і художнім світом дистанціює їх один від одного, аж до повного відсторонення автора від зображуваних подій.

Головна його функція в данному випадку - зіткнення цих начал, створення парадоксального світу, де реальне й фантасмагоричне співіснують за принципом взаємодоповнення, на межі буття й інобуття.

В цілому, якщо визначати основу близькості цих творів, треба сказати, що вони диктуються враженим авторським поглядом. Приголомшення зрушує звичні обриси дійсності: дії й ознаки майже не відповідають своїм предметам, це знаходить своє відображення в стилістиці - зокрема, в надлишку яскраво індивідуалізованих словосполучень. У них доцільність багатьох звичних взаємозв'язків постає зруйнованою. I в зв'язку з цим виявляється ще одна характеристика авторського погляду, що позначилася в художній структурі творів: він не тільки вражений, але й зупинений. Саме через цей авторський погляд реалізується особлива, а саме - імовірнісна картина світу (термін В. І. Тюпи) тобто автор не диктує свого бачення того, що відбувається, а лише пропонує варіанти. Варіативність трактування передбачається не тільки відносно окремих елементів (чи то язичницький бог, чи то волоцюга, що справляє природну потребу в «Пані», чи то статуя Христа, яка ожила, чи то п'яна галюцинація в «У святого Валента» у Бабеля). Точно так же варіативно трактується й смисл цілого («Цинамонові крамниці» - це і максимальне вираження егоцентричного типу свідомості і індивідуальної міфології, і таке ж напружене вираження свідомості безособистісно-міфологічної, розчиненої у всесвіті. «Кінармія» - і зображення культурного космосу, що розпадається в хаос, і навпаки - створення 3 хаосу нового космосу).

Ми пояснюємо східні особливості художніх світів даних творів тим, що перехід від модернізму до постмодернізму конституює особливий тип тексту. В усякому разі, в кожному з цих творів $є$ закономірності, які не вкладаються в межі модерністського світовідчуття, хоча й безумовно ним породжуються. 
Модерністська провокація абсолюта обертається звичною, постійною десакралізацією у І. Бабеля («єврейський бог в склянці чаю») або багатобожжям за принципом нонієрархії у Б. Шульца.

Крім того, обидва автори працюють на межі мистецтва слова і життя, проблематизуючи неперехідність цієї межі. І в принципі обидва автори відображають момент, коли людська свідомість починає жити в світі антиномій, які не можуть бути примирені вже ніколи й ніде, які, проте, неможливо не примиряти. В розібраних нами творах відображаються два способи життя з такими антиноміями: відчуття їх взаємооборотності й творчих можливостей, що випливають 3 цієї ситуації: гри, вибору (Б. Шульц) і випробування реальності на міцність в постійному й свідомому зіткненні світу і людини, сакрального й профанного, естетичного та антиестетичного (І. Бабель).

\section{ЛІТЕРАТУРА}

1. Лейдерман Н. Л. «И я хочу Интернационала добрых людей» (Национальные голоса и общечеловеческие святыни в «Конармии» Бабеля). Русская литературная классика ХХ века. Екатеринбург: Издательство УГПИ, 1996. С. 65-73.

2. Мних Р. «Цинамонові крамниці» Бруно Шульца : проблема жанру. Повернення. Бруно Шульи (1892-1942). Люблін : Видавництво Брама Гродська - Театр NN, 1996. С. 55-58.

3. Sandauer A. «Rzesgradovana rzestvitelnost...» Przedmowa. Schulz B. Proza. Kraków : Wydawnictwo Literackie, 1964. S. 25-26.

4. Шульц Б. Портрет в зеркалах / Публикация Б. Дубина. Иностранная литература. 1996. № 8. С. $159-180$.

5. Шалата М. Дрогобицька повість-химерія Бруно Шульца. Повернення. Бруно Шульи (1892-1942). Люблін : Видавництво Брама Гродська - Театр NN, 1996. С. 38-42.

\section{REFERENCES}

1. Leiderman, N.M. (1996) "'I also want International of good people' (National voices and general human holy shrined in 'Konarmia' Babel)", Classics of Russian Literature of the XX century ["I ya hochu Internacionala dobryh lyudey' (Nacionalnye golosa i obshchechelovecheskie svyatyni v 'Konarmii' Babelya), Russkaya literaturnaya klassika XX veka], UGPI, Ekaterinburg, 1996. pp. 65-73. (in Russian).

2. Mnikh, R. (1996), “'The cinnamon shops' by Bruno Schulz: problem of genre”, Return. Bruno Schulz (1882-1942) ["Tsynamonovi kramnytsi" Bruno Shultsa: problema zhanru, Povernennia. Bruno Shults (1892-1942)], Vydavnytstvo Brama Hrodska - Teatr NN, Lublin, pp. 55-58. (in Ukrainian).

3. Sandauer, A. (1964), “'Degraded realitu...', Preface, Schulz B. Prose [«Rzesgradovana rzestvitelnost...» Przedmowa, Schulz B. Proza], Wydawnictwo Literackie, Krakow, pp. 25-26. (in Polish).

4. Schulz, B. (1996), "Portrait in mirrors", B. Dubin (publ.) [Portret v zerkalakh. Publikaciya B. Dubina], Inostrannaya literatura, No. 8, pp. 159-180. (in Russian).

5. Shalata, M. (1996), "Drogobych story-himerija of Bruno Schulz", Return. Bruno Schulz (18821942) [Drogobicka povist-khymeriia Bruno Shulca, Povernennya. Bruno Shults (1892-1942)], Vydavnytstvo Brama Hrodska - Teatr NN, Lublin, pp. 38-42. (in Ukrainian). 